\title{
Sobre las leyes
}

\author{
Marco Tulio Cicerón \\ Edición bilingüe. Traducción, nOtas E Introducción de Laura E. Corso de Estrada (2019) \\ Colihue Clásica, Buenos Aires. \\ CXXXII + 294 pp. ISBN 978-950-563-038-7
}

\section{Francisco Bertelloni}

Universidad de Buenos Aires / CONICET, Argentina

De ninguna manera parece necesario justificar la inclusión de un comentario sobre una nueva traducción de un texto de Cicerón en una revista consagrada al pensamiento patrístico y medieval. Esa justificación parece tanto más superflua cuanto que se trata del De legibus. Como lo pone de manifiesto la extensa, rica y erudita "Introducción" de Laura Corso de Estrada (LCE), este tratado ciceroniano logró ejercer una vastísima influencia sobre el medio intelectual del mundo occidental pagano y, quizá más todavía, sobre el mundo cristiano, ya desde los primeros siglos. En esta breve nota me interesa aludir, sintéticamente, a esa y a otras características de este libro que está articulado, fundamentalmente, en tres grandes partes: Introducción, traducción al castellano con texto latino a página enfrentada y un Apéndice.

La Introducción es un extenso ensayo, de más de 130 páginas, en el que LCE muestra su buen conocimiento de las fuentes de Cicerón, de su pensamiento y de sus repercusiones e influencias. La primera información que recibe el lector concierne a la naturaleza de la obra ciceroniana como obra filosófica. Si bien no es nueva la tesis que sostiene que Cicerón es un auténtico filósofo y no un simple transmisor de filosofías ajenas, se trata de una tesis que asume una muy especial relevancia por dos motivos: primero, porque ello cambia el perfil de la figura de Cicerón y, a la vez, incrementa la importancia del pensamiento clásico latino; y segundo, porque es una tesis que ha llegado hasta hoy envuelta en la controversia. En efecto, aunque esta tesis no ha sido unánimemente admitida, sin embargo, ella parece haberse impuesto entre la crítica, sobre todo entre los estudios más recientes. Al respecto conviene señalar aquí que, luego de recorrer la literatura crítica sobre este aspecto de la obra de Cicerón -desde los autores que lo niegan hasta los que le atribuyen originalidad filosófica-, la traductora se coloca entre quienes sostienen que el perfil intelectual del Arpinate es el de un verdadero filósofo que aspira a expresar un pensamiento propio. Según sus propias palabras: "nos non interpretum fungimur munere" (De finibus, I.2.6).
Después LCE se ocupa de la datación del tratado -que, aunque es uno de los primeros de la obra de Cicerón, fue redactado en un momento de su vida de plena madurez, aproximadamente a sus 54 años- y de su inserción dentro del itinerario intelectual ciceroniano, para transitar de inmediato hacia un análisis del estilo dialógico y aporético, estilo este asociado al denominado "probabilismo" ciceroniano que, sin embargo, no le impide adherir decididamente a numerosas posiciones filosóficas, sobre todo a aquellas referidas al ius y a la lex que son, en este volumen, los núcleos temáticos sobre los que la traductora LCE insiste con más énfasis.

En efecto, es sobre todo en las páginas dedicadas a la ley natural y la antropología donde el lector encontrará la contribución teórica más rica de este libro, es decir, lo que concierne directamente al pensamiento filosófico de Cicerón sobre el ius naturae, tema que ya había sido anunciado así en la Introducción: "Cicerón sostiene la existencia del derecho natural (ius naturae) como una fuerza (vis) directiva del obrar humano, el cual debe su nombre a que, precisamente, tiene su origen en la naturaleza (in natura), pues como se enfatiza en el pasaje, no procede de la opinión (opinio) de los hombres" (p. ix). Enunciado de este modo, no parece necesario hacer alguna aclaración, primero, acerca de la relevancia, hasta nuestros días, de esa tesis por sí misma como problema teórico-filosófico; y segundo, acerca de la vastísima influencia que esa tesis logró ejercer sobre el mundo cristiano patrístico, medieval y moderno, por lo menos, hasta Thomas Hobbes.

El problema del ius naturae es complejo y al mismo tiempo fascinante. A título simplemente informativo mencionaré aquí, causa brevitatis, solo algunos pocos de sus aspectos más relevantes tal como son apuntados por LCE en esta Introducción: la necesidad que formula Cicerón de plantear el problema del ius y la lex en sede filosófica; la universalidad de ius y lex más allá de los límites de esta o aquella comunidad; el tercero, que prácticamente se colige de los anteriores, es la naturaleza humana como origen de las leyes por las cuales deben regirse las ciudades; y por fin la definición de lex según la formulación de De legibus II.4.8, que ha 
logrado trascender siglos de historia del pensamiento y que, por adhesión o por rechazo, se ha transformado en la definición clásica por excelencia de la ley natural: "primera y suprema ley es el entendimiento del dios que, conforme a la razón, establece las obligaciones y las prohibiciones". La correlación entre natura, ratio y lex para Cicerón es clara, y a partir de ella el lector podrá deslizarse a través de los teoremas ciceronianos acerca de la lex y su finalismo perfectivo que el Arpinate expone a lo largo de todo su tratado.

Luego de la Introducción, que incluye además un extenso parágrafo sobre las distintas fases de la filosofía ciceroniana sobre el hombre, sobre el ius y la lex, otro dedicado a la estructura temática del De legibus, una cronología de la vida de Cicerón y una muy actualizada bibliografía, el volumen ofrece la cuidadosa traducción española, a página enfrentada con el original latino, y un apéndice sobre las posteriores proyecciones de la tradición ciceroniana de la ley natural. En síntesis, con este libro se concreta un intenso trabajo de investigación realizado a lo largo de años, y ve la luz un volumen resultante de la colaboración de su autora con la editorial Colihue, empeñada en su colección clásica en ofrecernos textos de la tradición intelectual de Occidente. 